\title{
Amtsfysikus Christian Lintrups virke i Hedemarkens amt i årene 1800-31
}

\author{
Sammendrag \\ Bakgrunn. De første tiårene etter 1800 \\ var Norge preget av krig, uår, fattigdom \\ og epidemier, og de få offentlige leger \\ som fantes, arbeidet under vanskelige \\ forhold.
}

Materiale og metode. Artikkelen bygger på gjennomgang av medisinalmeldinger fra perioden 1804-31 og korrespondanse mellom amtsfysikus Christian Lintrup (1768-1844) og andre offentlige leger i Hedemarkens amt og amtmannen, deres administrativt overordnede.

Resultater. Lintrup var født i Danmark og tok medisinsk universitetseksamen i 1798 i København. Han ble utnevnt til amtsfysikus i Hedemarkens amt i 1799. Legene hadde grunnlønn, og deres inntektsmuligheter fra privat praksis var usikre, særlig i landdistriktene. De mange sykebesøkene medførte lange og tidkrevende reiser. Bruk av kvakksalvere var vanlig, ikke bare blant fattige. Lintrups virke var preget av opplysningstidens rasjonalitet og kunnskapstro, noe som blant annet fremkommmer gjennom hans omtale av psykotiske pasienter. Han sto bak ansettelsen av offentlige jordmødre og brukte mye tid på reiser i amtet for å drive opplysningsvirksomhet og koppevaksinering.

Fortolkning. Christian Lintrup og hans kolleger lyktes med å utvikle og konsolidere et lokalt helsevesen selv om de hadde få ressurser. Det ga grobunn for de senere distriktslegers virke og for utviklingen av et moderne offentlig helsevesen i Norge.
Hans Petter Schjønsby

schoejn@online.no

Kongsveien $37 \mathrm{~B}$

2380 Brumunddal

Christian Lintrup (1768-1844) var amtsfysikus i Hedemarkens amt fra 1800 til 1831 og tilhørte den generasjon norske offentlige leger som var med på å bygge opp og sette preg på sin samtids helsetjeneste. De fleste av dem ble utnevnt i løpet av de siste par tiårene før 1800 som en følge av kongens satsing på et offentlig helsevesen. Bakgrunnen for denne prioriteringen var mangesidig: årvisse epidemier, i Norge radesyken, den høye barnedødeligheten og den eneveldige stats behov for en frisk befolkning. Samtidig frembrakte opplysningstiden ny medisinsk viten og en fremtidstro som la grunnlaget for store fremskritt på 1800-tallet (1).

Denne utviklingen inkluderte også opprettelse i 1803 av Sundhedscollegiet, et nytt sentralorgan for tilsyn med og administrasjon av helsetjenester. Som følge av krigen i 1807-14 fikk Norge sitt eget sunnhetskollegium i 1809. Det var i virksomhet frem til 1815. Kollegiet, som var faglig overordnet alle offentlige helsetjenester i Norge, var sammensatt med leger, jurist og apoteker og ble ledet av en av landets fremste medisinere på den tiden, Magnus Thulstrup (1769-1844) (2). Det ble også opprettet sykehus i amtene for isolering og behandling av pasienter med venerisk sykdom. Denne interessante moderniseringsprosessen av helsetjenesten er godt beskrevet av flere nåtidshistorikere $(1,3)$.

Pionergenerasjonen av offentlige leger arbeidet under vanskelige vilkår. De første tiårene etter 1800 var Norge preget av epidemier og befolkningskriser, krig, uår og fattigdom. Samtidig var det uorden i pengevesenet, og i 1813 var landet bankerott. Etter krigen og begivenhetene i 1814 var statsgjelden høy, og med inflasjon tok det lang tid før det igjen var vekst $i$ landet. Oppbyggingen av et offentlig helsevesen ble initiert og påbegynt under et sentralistisk styrende enevelde med aktive fagorganer (kollegiene) og fortsatte under en demokratisk styreform som embetslegene måtte tilpasse seg. De faglige innspill ble nå gitt på departementets premisser, og avstanden til overordnet faginstans ble lengre.

\section{Kildene}

Hovedkildene for denne artikkelen er medisinalmeldinger og korrespondanse mellom legene og deres administrativt overordnede, amtmannen i Hedemarken amt, fra perioden 1804-31. Medisinalmeldingene var årlige innberetninger fra legene til de sentrale helsemyndigheter om helseforholdene i deres tjenestedistrikter. De var utformet etter en mal og innført fra og med året 1804 for å skaffe de styrende et bedre beslutningsgrunnlag. Kvaliteten på meldingene varierte sterkt. Dette ble tidlig et problem, og i et skriv til departementet i 1815 fant sunnhetskollegiet å måtte vurdere legenes dyktighet - målestokken var medisinalberetningenes kvalitet (4). Amtsfysikus Christian Lintrup kom godt ut av denne vurderingen og ble rangert $\mathrm{i}$ gruppen av de ti beste legene som «udmærkede sig i Særdeleshed med Hensyn til Udførlighed og Nøiagtighed». Det er bevart 17 meldinger etter Lintrup, og alle er omfattende, systematiske, grundige og velskrevne.

Lintrups virksomhet er godt dokumentert. Korrespondansen med amtmannen omfatter 625 brev om embetssaker og «Medicinalvæsenet angaaende». I tillegg korresponderte han med de sentrale myndigheter, som sunnhetskollegiet.

\section{Legene}

Den medisinske profesjon var da ganske ny i Norge. På midten av 1700-tallet var det totalt bare 10-12 leger her i landet, og bare én av disse hadde sitt virke utenfor byene (5). Reformer førte til at antallet autoriserte leger i 1800 var steget til 17 og i 1803 til 33 (6). Legetjenester ble også ytet av militærleger, dvs. feltskjærer og kirurger med ulik utdanning og av ymse kvalitet. Antallet av disse

\section{Hovedbudskap}

- De første tiårene etter 1800 i Norge var preget av krig, nød og epidemier

- De få offentlige legene som fantes, de aller fleste utdannet i Danmark. arbeidet under vanskelige forhold

- Christian Lintrup, amtsfysikus i Hedemarkens amt i årene 1800-31. var preget av opplysningstidens ideer

- Lintrups medisinalberetninger gir interessante innblikk i folkehelse og helsetjenester tidlig på 1800-tallet 
økte under krigen, fordi det ble tatt inn mange, ofte «uexaminerede», militærleger utenfra, slik at det i 1816 var 100 autoriserte leger i Norge, hvorav 27 ueksaminerte (7).

\section{Lintrups bakgrunn}

Lintrup var født i Danmark og tok medisinsk universitetseksamen i 1798. Allerede fra 1793 arbeidet han som kandidat ved Det Kongelige Frederiks Hospital i København. I 1799 ble han oppført som «Licentiatus», altså doktorgradskandidat med forelesningsplikt, etter datidens forståelse av begrepet. Sykehuset var også opplæringssted for kirurgistudenter og kandidater. Forutsetningene for en god legeutdanning var til stede, og sykehuset ble tidlig en prestisjeinstitusjon (8). Lintrup var altså en meget velutdannet og bredt skolert ung lege da han ble utnevnt til amtsfysikus i Hedemarkens amt i 1799 (fig 1).

\section{Arbeidsforhold og levekår}

Lintrups første brev til amtmann Andreas Høyer (1742-1817) er datert 1. september 1800 og handlet - ikke uventet - om penger. Legene hadde grunnlønn, og det ble forventet at inntekten ble justert ved privat praksis. Grunnlønnen var lav, den tilsvarte omtrent gasjen til tollbetjenter, kapellaner og sogneprester i små kall (9). Inntektsmulighetene fra privat praksis var usikre, særlig i landdistriktene. Dette hadde naturlig nok sammenheng med at denne generasjonen leger var den første av sin stand i de fleste distrikter og dermed måtte opparbeide seg tillit i befolkningen. Derfor klaget mange av embetslegene, også Lintrup, over lønnsforholdene.

I et brev til kongen noen måneder senere ba Lintrup om lønnsforhøyelse (fig 2). I brevet ga han et bredt og godt bilde av en offentlig leges arbeid, levekår og bekymringer på denne tiden. Særlig prøvde han å dokumentere gapet mellom sine inntektsmuligheter og de økende leveomkostningene:

Den Gage jeg nyder, blev reglementeret paa en Tiid, da alle Livets Nødvendigheder kunde kiøbes for halve eller maaskee tredie Deelen af hvad de nu koste. I min lille Huusholdning som visselig er saa tarvelig og indskrcenket som mueligt (en Sandhed som enhver, der kjender min huuslige Forfatning, kan bekrcefte) udfordres til Kornindkjøb med 120 rd, til Kiødvare henimod $40 \mathrm{rd}$, til Huusleie og Fourage for nødvendige Kreature 60 rd; og naar hertil kommer Folkeløn, og Indkiøbet af saa mange andre Nødvendigheder, saa beløber alt dette sig til en Summa, vel dobbelt saa stor som min Gage, og endda skal Gjeld afbetales som ikke kan staa, uden at giøre om mueligt, nye endnu større Gield.

Embetslegene hadde ingen tjenestebolig, slik for eksempel prestene og offisersstanden

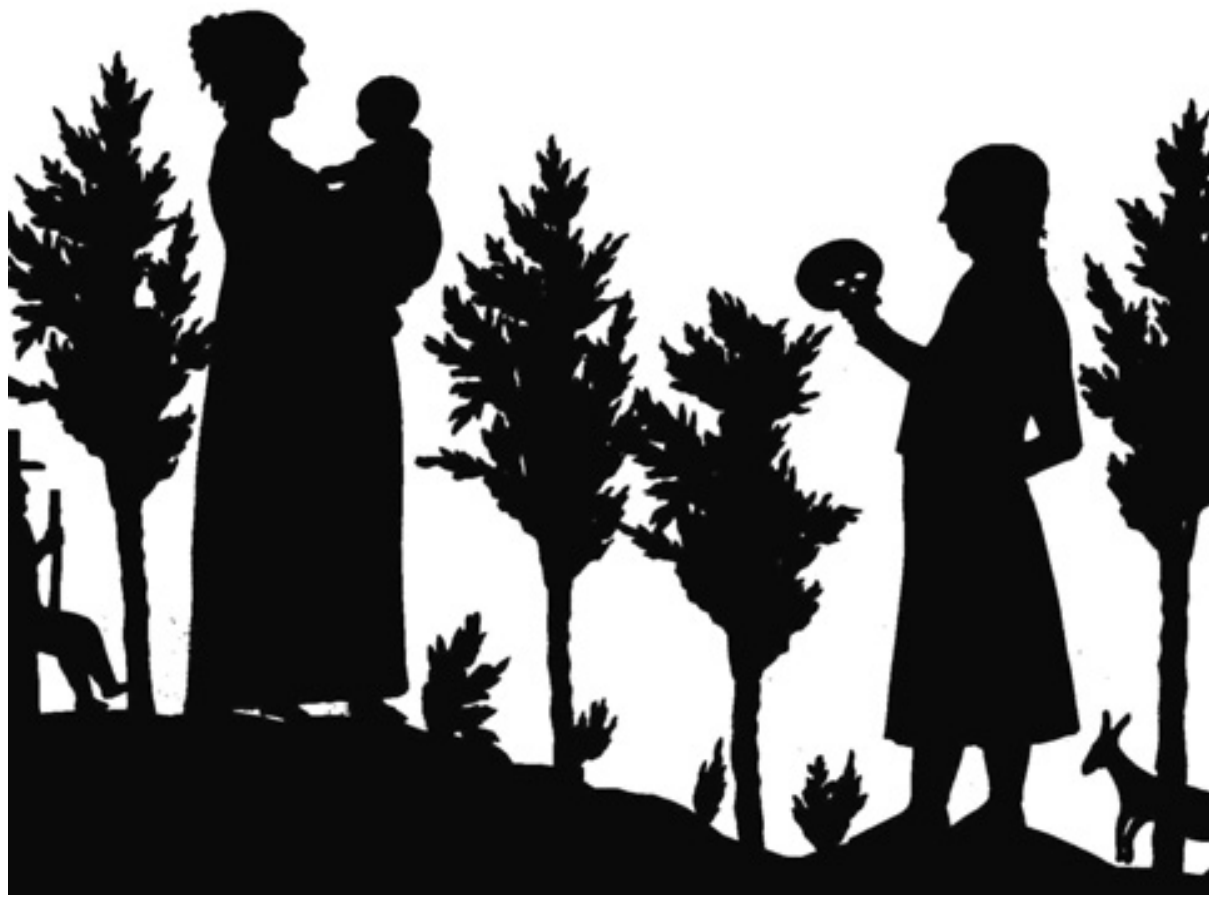

Figur 1 Amtsfysikus Christian Lintrup og hans familie. Lintrup står sammen med sin kone Johanne f. Hoelfeldt. Hun bærer sin førstefødte på armen og er gravid med ekteparets neste barn. Helt til venstre Lintrups far, sogneprest Jens Lintrup. Silhuett, ca. 1801. Privat eie

hadde. De måtte leie seg inn, på landet gjerne hos en gårdbruker, før de kunne kjøpe seg eget bosted. Fordi de var embetsmenn og tilhørte de kondisjonerte, måtte de opprettholde en viss levestandard, og det kostet.

Sykebesøk utgjorde en vesentlig del av legenes praksis. Infrastrukturen var lite utviklet. Legene var få og distriktene store. Dette medførte lange, slitsomme og tidkrevende reiser med mange skysskifter og primitive overnattinger. En tjenestereise for Lintrup fra Stange til nord i Østerdalen kunne ta nærmere to uker, og en slik yrkepraksis tok på.

\section{Lintrup og hedmarkingene}

Lintrup kom fra en urban københavnerkultur til innlandet i Norge, og det var uunngåelig at han kom til å gi uttrykk for at denne overgangen kunne by på problemer. Vi ser dette spesielt i forhold til bøndene, og særlig på Hedemarken, dvs. de nåværende kommunene Hamar, Løten, Ringsaker og Stange, som var Lintrups kjerneområde. Ofte handlet det om økonomi og om det han kalte bøndenes «Uskiønsomhed»:

Min Erfaring har loert mig, at Bonden uden Modsigelse betaler mange Rigsdaler til en reysende Qvaksalver; naar han derimod neppe vil betale et par Mark til den ordentlige Lage, thi da han veed, at Lagen faar aarlig Løn, saa troer han, at denne er forpligtet til at hjolpe ham uden Betaling.

Men Lintrup skilte mellom bøndene:
... der gives mange Undtagelser, iscer blant Bønderne i Aamodt og Elverum, hvor min Praxis har skaffet mig saamegen Fortieneste, at jeg umuelig uden denne skulde have havt det nødtørftige Udkomme.

Lintrup klaget også over overtroen i befolkningen. Han forklarte den ved at opplysningsnivået hos den vanlige mann var lavt, og at det var grunnen til at så mange «saa kaldte kloge Mænd og Qvinder» kunne leve av å helbrede sykdommer ved å lese over dem.

\section{Men dette Uvaesen er blot en Følge af Enfoldighed, eller Mangel paa bedre Oplysning; thi man hører intet til dette $i$ Elverum eller Aamodt, hvor Bønderne ere ualmindelig oplyste, da man endog $i$ disse 2de Prostegjelde finder Lase- selskaber, hvor saavel mange moralske, som oeconomiske Skrifter holdes og loeses med Nytte.}

Lintrup kan ha et poeng her, selv om bruk av kvakksalvere ikke var forbeholdt dem uten utdanning. De angitte leseselskapene i Østerdalen var i virksomhet allerede før 1800, mens det første leseselskapet i det største prestegjeldet på Hedemarken, Ringsaker, ble etablert først i 1837 (10). Lintrups reaksjoner gjenspeilte brytningstiden der de mange konservative og stødige bøndene, som var vant til å stole på seg selv, ikke uten videre godtok forhold de mente ble påtvunget dem ovenfra, særlig ikke hvis de måtte betale for dem: 
Ncesten overalt maatte jeg med Bekymring erfare, at Loge og Logemidler ingen Tiltroe finde for den almindelige Mand, saa at Nytten af mine med Bekostninger og Bevarligheder forbundne Reiser, er meget tvivlsom.

\section{Psykiatri på Hedemarken i 1801}

Et godt eksempel på denne brytningstiden har vi fra 1801, da Lintrup ble tilkalt for å se til en psykiatrisk pasient i Romedal (11). Det dreide seg om en ung gårdbruker som var blitt akutt psykotisk «og ganske berøvet Fornuftens Brug». Han var så voldelig at «man har været nødsaget til at slaae ham fast i Væggen med Laas og Lænker», skrev lensmannen til fogden. Lintrup oppsøkte den syke og rapporterte tilbake til amtmannen at pasienten mot formodning var stille og vennlig og så fornuftig

at jeg tog i Betcenkning strax at løse ham af Lonkerne, og lod ham saa folge mig til Lensmanden, hvor alle de noervarende vare Vidner til at han noesten ikke en gang kunde ansees som vanvittig.

Lintrup tok opp sykehistorie for om mulig å finne årsaken til sykdommen. Dette var ingen selvsagt handling i datiden. Vanligvis ga legene brekkmiddel, foretok årelating eller lakserte pasienten uten å bry seg om årsaksforhold. Lintrup fant at psykosen hadde sammenheng med at gårdbrukeren nylig hadde overtatt en landbrukseiendom og hadde stor gjeld. Det var blitt for mye for ham, og Lintrup mente pasienten måtte ha hjelp av samfunnet for å komme seg ut av uføret.

Lintrup var preget av opplysningstidens

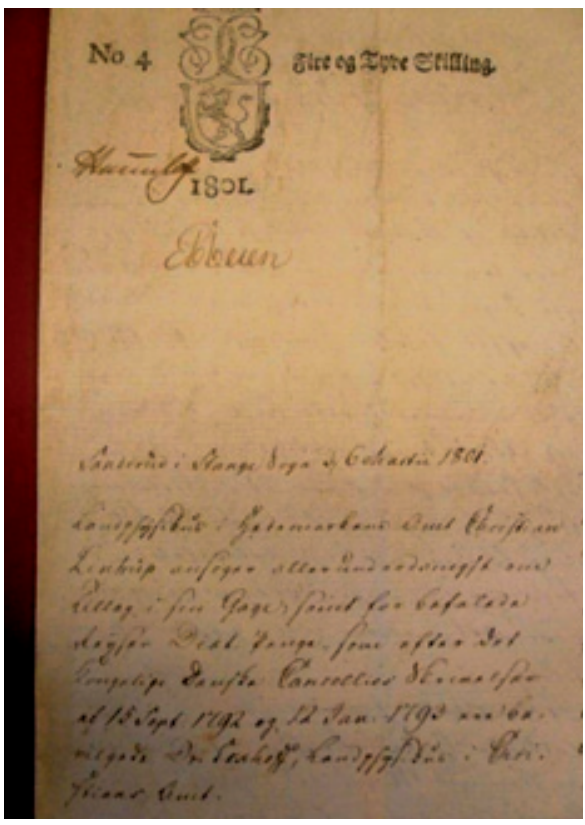

Figur 2 Utsnitt av brev datert 6. mars 1801 fra amtsfysikus Christian Lintrup til kongen, der han ber om lønnsforhøyelse. Foto Statsarkivet i Hamar rasjonalitet og kunnskapstro, og i stedet for gammeldags behandling hadde han en humanistisk tilnærming til pasienten og hans problemer. Slike holdninger hadde begynt å vinne innpass på kontinentet (12).

\section{Embetslegens offentlige arbeidsoppgaver}

Ved siden av kurativt arbeid på individplan preget tre samfunnsmedisinske hovedoppgaver arbeidet til de offentlige legene i denne pionerperioden: etablering og utvikling av en offentlig jordmortjeneste, oppfølging av koppevaksineringen, som ble iverksatt på denne tiden, og det forebyggende arbeidet i distriktene med årvisse infeksjonssykdommer, befolkningskriser og ernæringsproblemer. Dette var særlig viktig i forbindelse med krigen og nødsårene 1808-14.

Et annet viktig arbeidsfelt var rettsmedisinske oppgaver, spesielt plutselig spedbarnsdød. Årsaken var rettsforfølgelsen på 1700- og 1800-tallet av unge kvinner mistenkt for barnedrap, der embetslegenes rapporter var viktige (13). Dette arbeidsområdet illustrerer datidens inhumane strafferettspleie basert på kong Christian Vs landslov fra 1687, som først ble avløst av en ny kriminallov i 1842 .

\section{Jordmortjeneste og fødsler}

Jordmorvirksomheten i Norge ble lovregulert i 1810. Regelverket var svært omfattende. En fødsel ble en offentlig sak. Jordmødrene ble underlagt legene, og prestegjeldene ble delt opp i jordmordistrikter. Det tok noen tiår før jordmortjenesten fikk fotfeste i befolkningen, som hadde samme motforestillinger mot bruk av eksaminerte jordmødre som de hadde mot legene.

Lintrup, som var aktiv i arbeidet med ansettelse av jordmødre og kjente flere av dem, opplevde denne kulturkollisjonen på nært hold. Husmannsjenta Marthe Johannesdatter (1777-1844) kom som eksaminert jordmor fra København tilbake til hjembygda Ringsaker i 1806 . Etter noen år viste det seg at hun ikke hadde nok å gjøre, på tross av at hun var eneste jordmor i et prestegjeld med med en befolkning på nesten 7 000. Lintrup gikk nøye inn i saken og fant snart ut at det dreide seg om at

den almindelige Mistillid til hende skal komme deraf at hun paa et Sted hos en conditionnered Familie havde en Forretning, hvor Vending var nødvendig; og under denne gik den svage og om Fosteret viklede Navlestreng i Stykker; hun ansaae det altsaa nødvendig, at løsne og udtage Efterbyrden. En tilstedevarende respectabel Dame ville forstaae Tingen bedre, og forbød hende, eller satte sig imod denne Operation; Giordemoderen derimod agtede ikke forbudet af den ukyndige og dog paastaaende Person, men giorde hvad hun burde.
Men ryktet om dårlig jordmorarbeid var satt ut. I sitt brev til sunnhetskollegiet i Christiania om saken føyde Lintrup til at resultatet rettferdiggjorde jordmorens handlemåte: Barnet levde og var friskt (14). Denne hendelsen illustrerte datidens sosiale system og de store klassemotsetningene. Den viste også embetslegen som sto opp for en jordmor og plasskjerring i en vanskelig situasjon. Med hjelp fra sunnhetskollegiet fikk han plassert Marthe som jordmor i Elverum, der hun døde 35 år senere.

Det foreliggende arkivmateriale viser at det er svært sjelden at en embetslege i et rigid standssamfunn har intervenert i saker til fordel for den svakere part, slik Lintrup her gjorde.

\section{Koppevaksinering}

Sommeren 1803 reiste Lintrup gjennom Østerdalen for «at indføre Vaccinationen». Den første koppevaksineringen her til lands ble foretatt i 1802, og de offentlige legene ble raskt bedt om å organisere vaksinering i sine distrikter. Rapportene som Lintrup sendte til amtmannen, ga et godt bilde av denne prosessen. Vanskelighetene var flere. Vaksinen var ikke alltid patent og slo ikke alltid an, kommunikasjonen med befolkningen var ofte ikke tilfredsstillende, men det største problemet var nok motstanden på bygdene.

Lintrup brukte mye tid på reiser og opplysningsvirksomhet vedrørende koppesykdommen. Han foretok systematiske vaksinasjonsreiser gjennom amtet. Oppslutningen om vaksineringen økte, særlig etter at dette ble gjort obligatorisk ved eget lovverk i 1810. Etter dette brukte Lintrup mye tid og krefter på å bygge opp et kompetent korps av autoriserte hjelpevaksinatører i alle prestegjeld. I 1810 brøt det ut kopper i Rendalen. Lintrup ville da vaksinere den yngste delen av befolkningen, men tre unge bønder motsatte seg vaksinering av sine barn så sterkt at Lintrup måtte ha militær eskorte for å gjennomføre innpodingen. Sunnhetskollegiet reiste sak mot de tre bøndene, som fikk merkbare bøter (2). Slik bruk av tvang fra myndighetene, bare fire år før systemskiftet i 1814, viser en av de mørke sidene ved eneveldet, nemlig dets strenge og rigide lovanvendelse for å oppnå allmennhetens lydighet overfor øvrigheten og dens påbud.

Den «almindelige Vrangvillighed» hos flesteparten av hedmarkingene ga seg imidlertid etter hvert, og allerede i medisinalmeldingen i 1827 kunne Lintrup skrive:

Vaccination er almindelig udbredt $i$ Districtet og møder nu ingen Modvillie fra Almuen, der har begyndt at indsee dens velgiørende virkning.

Lintrups innsats ble lagt merke til (15). I 1815 skrev sunnhetskollegiet blant annet følgende om koppevaksineringen: 
Dog fortjener Physicus Lintrup paa Hedemarken ligesaameget at bemorkes, da han er blant de Physici, der har anvendt mest Umage og Flid paa at oploere Hjoelpevaccinateurer $i$ hans vidløftige Embedsdistrict.

\section{Epidemier og smittsomme sykdommer}

Demografiske kriser kan defineres som perioder med stor konsentrasjon av dødsfall (16). De skyldtes vanligvis epidemisk sykdom, ofte kombinert med krig, uår og vanskelige ernæringsforhold. Her i landet oppsto slike kriser i årene 1741-43, 1771-73 og på 1800-tallet i 1801 og i nødsårene 1808-09 og 1813. Under alle disse krisene fant det sted en avflating eller en nedgang $\mathrm{i}$ befolkningsveksten.

Amtsfysikus Lintrup ble raskt etter at han tiltrådte sin stilling konfrontert med en krise. I februar og i juni 1801 dro han til Odalen og Solør etter innberetning og ilmelding fra lensmann, fogd og prest om en epidemi. Det var uår og hungersnød, og kapellan Bloch skrev at han

dagligen hadde det smertelige Syn at ikke se Mennesker, men sorte, uttcrede Skygger. Noesten hele Odahlen Proestegjeld ser saaledes ud, og hvad Under, da Bark blandet med Rughalm og Bjørnemose hele Vinteren har udgjort de flestes Føde.

Blochs beskrivelse er malende. I et par dramatisk formede linjer skildrer han nedslitte og hardt rammede bygder der død og hungersnød herjer, samtidig som han er hjelpeløs overfor katastrofen. I Solør og Odalen døde det 165 flere enn det ble født dette året (17).

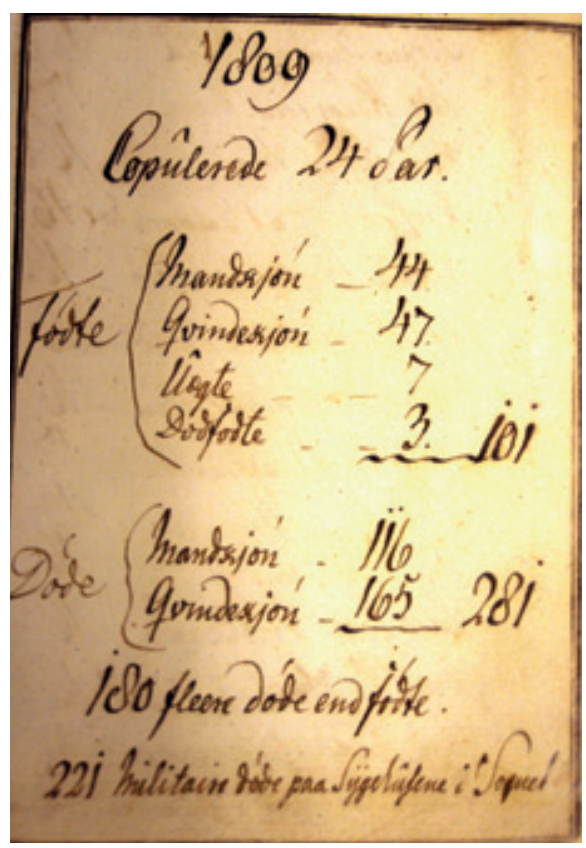

Figur 3 Dødeligheten i Odalen i 1809. Fra kirkeboken for Odalen prestegjeld
Lintrup mente at epidemien skyldtes «Forraadnelsesfeber». Datidens sykdomsforståelse var svært annerledes enn vår, og direkte sammenlikninger er vanskelig å foreta. I dag ville man ha antydet at det kan ha dreid seg om en tyføs sykdom, som tyfoidfeber eller flekktyfus. Lintrup kunne ikke gjøre stort. Den vanlige behandlingen den gangen var et brekkmiddel («Brækrod»), som man mente hjalp noen. I tillegg ble det også brukt rabarbrarot, som ble tillagt en stoppende virkning. Lintrup var nøktern når det gjaldt medikamentbruk og syntes for eksempel at årelating, som ofte ble forordnet, ikke hadde noen virkning:

de øvrige Patienter ere ved Naturens Hicelp kommet sig, naar ikke Aareladning eller andre skadelig Midler vare brugt.

\section{Krigsepidemiene}

Åtte år senere brøt det ut en dysenteriepidemi i store deler av amet, et ledd i en farsott som herjet store deler av Østlandet i 1809-10 og hadde sammenheng med krigen 1807-14. Det forelå smitte fra militærleirene, der langt flere døde av smittsom sykdommer som dysenteri, flekktyfus og tyfoidfeber enn av krigshandlinger. Smitte til sivilbefolkningen skjedde lett (fig 3). Det var også en dysenteriepidemi i 1813, men da var det ingen krigshandlinger, og antallet døde var ikke så høyt.

Ut fra kirkebøker og folketellingen i 1801 kan det beregnes at dødeligheten i Vinger og Odalen i 1809 var 65,9 per 1000 innbyggere, og omtrent det samme i 1813. På landsbasis var tallene henholdsvis 35,4 og 28,9 . Tallene for de militære var enda verre. Fra høsten 1808 til våren 1809 lå sykeligheten på over 500 per 1000 innbyggere (18).

\section{Lintrup og hans generasjon av offentlige leger}

Så vidt vi kan se av kildene, kan Christian Lintrup ha skilt seg ut fra mange av sine kolleger ved sin allsidighet. Han var meget velutdannet, hadde relevant erfaring og viste seg snart som en god og effektiv organisator. Lintrup var tidlig ute med koppevaksinering i amtet, og da dette ble lovpålagt i 1810 , skapte han raskt et godt og solid vaksinasjonssystem. Det samme gjaldt jordmortjenestene.

Christian Lintrup var også en god kliniker. Det kan vi blant annet se ut fra hans interessante og omfattende pasientjournaler fra amtssykehuset på Sanderud, noen av dem skrevet på latin. Han studerte i København i opplysningstiden og visste hva som rørte seg. Han var humanist og rasjonell i sin profesjonsutøvelse. Han var uredd og hadde en velutviklet rettferdighetssans. Arkivene kan fortelle at han ikke sjelden sto opp for dem han følte ansvar for, også dem som sto svakt $i$ et hardt og statisk standssamfunn.

Lintrups og hans kollegers virke som embetsleger fant sted i en svært vanskelig periode i landets historie. De lyktes likevel med å utvikle og konsolidere et lokalt helsevesen til tross for at de var få og hadde få ressurser til disposisjon. Likevel ble mye oppnådd, blant annet gjennom koppevaksineringen, noe befolkningen etter hvert forsto (3). De offentlige legene, blant dem amtsfysikus Lintrup, skapte tillit og dermed grobunn for de senere distriktslegers virke og for videreutviklingen av det offentlige helsevesen i Norge. Dette var kanskje deres største fortjeneste.

Oppgitte interessekonflikter: Ingen

\section{Litteratur}

1. Fra eneveldet til Kielfreden 1660-1814. I: Moseng OG, Opsahl E, Pettersen GI et al, red. Norsk historie 2 (1537-1814). Oslo: Universitetsforlaget, 2003 225-61.

2. Schjønsby HP. Sundhedscollegiet 1809-1815 Oslo: Statens helsetilsyn, 2009

3. Moseng OG. Formingen av et helsevesen. Ansvaret for undersåttenes helse. I: Schiøtz A, red. Det offentlige helsevesen i Norge 1603-2003. Bd. 1. Oslo: Universitetsforlaget, 2003: 163-265.

4. Sunnhetskollegiet Kopibok 1813-1815. Pk. 5, nr. 779. Oslo: Riksarkivet.

5. Utheim J. Det civile lægevesens Utvikling før 1814 I: Ot.prp. nr. 39 (1911). Om lov nr. 34 av 26. juli 1912 om utførelsen av de offentlige lægeforretninger.

6. Statskalendrene 1800 og 1803. Oslo: Riksarkivet.

7. Fortegnelse over de autoriserede Læger i Norge, samt over de i Embede ansatte uexaminerede Bataillons-Chirurger. Christiania: 3. Departement 1816.

8. Løkke A. Patienternes Rigshospital 1757-2007. København: Gads Forlag, 2007.

9. Dyrvik S. Den lange fredstiden 1720-1784. I: Mykland K, red. Norges historie. Bd. 8. Oslo: Cappelen, 1978: $310-34$

10. Feiring T. Kunnskap og kunst. I: Ringsakboka IV. Moelv: Brøttum, Ringsaker og Veldre historielag, 1998

11. Schjønsby HP. Psykiatri på Hedemarken i 1801. I: Gammalt frå Stange og Romedal. Stange: Stange historielag, 2002.

12. Porter R. Madness. Oxford: Oxford University Press, 2002

13. Schiøtz A. Svarene ligger i kroppen - barnemord $i$ lys av rettsmedisinens fremvekst 1750-1850. I: Historier om helse. Oslo: Den norske legeforening, 2009

14. Fylkesmannsarkivet. Brev fra leger. Brev fra amtsfysikus Lintrup til sunnhetskollegiet 26. februar 1813. Hamar: Statsarkivet i Hamar.

15. Malm 0. Kopper og Vaccination i Norge. Kristiania: Aschehoug, 1915: 75

16. Dyrvik S. Den demografiske overgangen. Oslo: Samlaget, 2004: 35

17. Skappel S. Hedemarkens amt 1814-1914. Kristiania: Grøndahl \& Søn, 1914

18. Angell H. Syv-aarskrigen for 17. mai 1807-1814 Kristiania: Aschehoug, 1914

Mottatt 17.6. 2010, første revisjon innsendt 1.10. 2010, godkjent 14.10. 2010.

Medisinsk redaktør Petter Gjersvik. 